SJ Quinney College of Law, University of Utah

Utah Law Digital Commons

$1-2020$

\title{
U.S. v. Briggs: Brief of Members of Congress As Amici Curiae in Support of Petitioner
}

Paul Cassell

John Ehrett

Allyson N. Ho

Bradley Hubbard

Philip Axt

See next page for additional authors

Follow this and additional works at: https://dc.law.utah.edu/scholarship 
Authors

Paul Cassell, John Ehrett, Allyson N. Ho, Bradley Hubbard, Philip Axt, Jodeph Barakat, and Thomas Molloy 
Nos. $19-108$ and 19-184

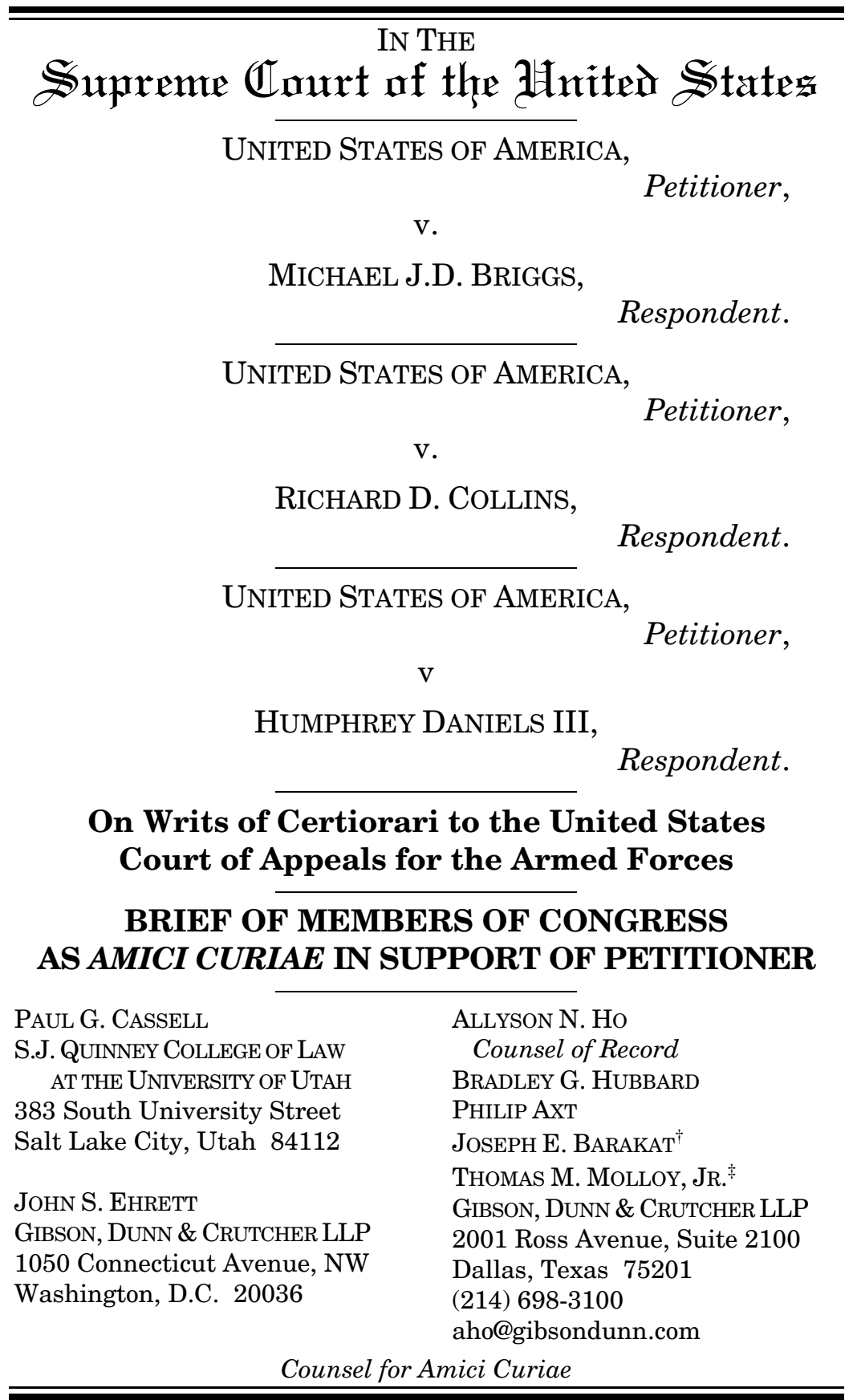

Admitted only in Washington, D.C.

\$ Admitted only in California. 


\section{TABLE OF CONTENTS}

Page

Table of Authorities.................................................. ii

Interest of Amici Curiae ............................................. 1

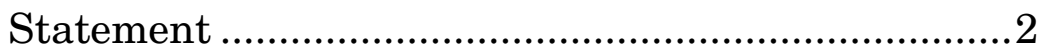

Summary of Argument................................................. 4

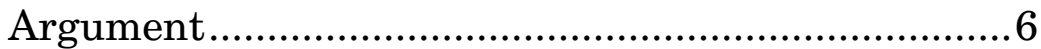

I. The Decision Below Undermines Congress' Authority Over Military Discipline By Rewriting The Uniform Code Of Military Justice.

A. Statutory Text And Structure Unmistakably Reflect Congress' Determination That No Statute Of Limitations Should Apply To Rape In The Military

B. Legislative History Confirms What Statutory Text Makes Plain: Congress Intended No Limitation On The Prosecution Of Rape In The Military. ...12

II. Congress Removed Any Limitations On Prosecuting Rape In The Military To Achieve Critical Policy Goals.

A. Congress Sought To Address The Unique Harms Associated With Rape In The Military.

B. Underreporting Poses A Particular Challenge To Prosecuting Rape In The Military...................................................18

Conclusion 
ii

\section{TABLE OF AUTHORITIES}

\section{Cases}

Page(s)

Burns v. Wilson,

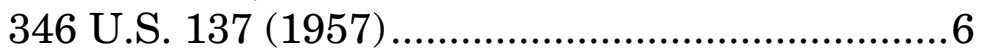

Chappell v. Wallace,

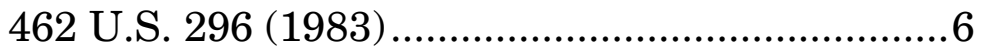

Coker v. Georgia,

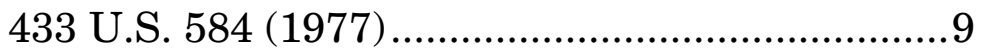

Coon v. United States, 411 F.2d 422 (8th Cir. 1969).................................13

Dynes v. Hoover, 61 U.S. (20 How.) 65 (1857) ................................... 6

Gustafson v. Alloyd Co., 513 U.S. 561 (1995)

Kennedy v. Louisiana, 554 U.S. 945 (2008) 8,16

Loving v. United States, 517 U.S. 748 (1996) .6

Smith v. United States, 568 U.S. 106 (2013) ..............................................

Solorio v. United States,

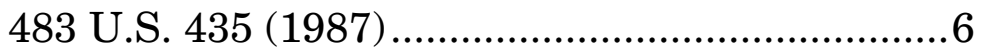

United States v. Ealy, 363 F.3d 292 (4th Cir. 2004)..............................12

United States v. Gallaher, 624 F.3d 934 (9th Cir. 2010)

United States v. Kennedy, 618 F.2d 557 (9th Cir. 1980). .13

United States v. Kubrick, 444 U.S. 111 (1979) 


$$
\text { iii }
$$

United States v. Mangahas, 77 M.J. 220 (C.A.A.F. 2018)..........................9, 10

United States v. Manning, 56 F.3d 1188 (9th Cir. 1995)................................11

United States v. Payne, 591 F.3d 46 (2d Cir. 2010) ...................................11

United States v. Stebbins,

61 M.J. 366 (C.A.A.F. 2005)..............................3, 9

Willenbring v. Neurauter, 48 M.J. 152 (C.A.A.F. 1998).....................3, 8, 9, 14

\section{Statutes}

10 U.S.C. § 843 (1994 \& 2000)

(UCMJ Art. 43) $2,8,10,14$

10 U.S.C. § 843 (2012 \& Supp. II 2014)

(UCMJ Art. 43) .14

10 U.S.C. $\S 843$ (2006 \& Supp. I 2007)

(UCMJ Art. 43) .13

10 U.S.C. $§ 843$ (1982)

(UCMJ Art. 43) .12

10 U.S.C. § 920 (1994 \& 2000)

(UCMJ Art. 120)

$2,7,8,10$

18 U.S.C. § 3148 (1976) .13

18 U.S.C. $\S 3281$ $11,12,13$

18 U.S.C. $\S 3282$ 11,12

Act of May 5, 1950, ch. 169, Pub. L. No. 81-506, 64 Stat. 107 (1950) 8

Enrollment Act, ch. 75, 12 Stat. 731 (1863) .8

National Defense Authorization Act for Fiscal Year 1987, Pub. L. No. 99-661, 100 Stat. 3816 (1986) 8,12 
National Defense Authorization Act for

Fiscal Year 2006, Pub. L. No. 109-163,

119 Stat. 3136

National Defense Authorization Act for

Fiscal Year 2014, Pub. L. No. 113-66, 127 Stat. 671 (2013)

\section{Legislative Materials}

H.R. Conf. Rep. No. 360, 109th Cong., 1st Sess. 703 (2005).........................14

H.R. Rep. No. 89, 109th Cong., 1st Sess. 332 (2005).........................14

Joint Explanatory Statement, 159 Cong. Rec. H7984 (2013)................................15

S. Rep. No. 331, 99th Cong., 2d Sess. 249 (1986) 13

\section{Constitutional Provisions}

U.S. Const. art. I, § 8, cl. 14 .6

\section{Other Authorities}

Dep't of Defense, Annual Report on Sexual Assault in the Military: Fiscal Year 2018 (Apr. 2019). 16,19

Dep't of Defense, Report of the Response Systems to Adult Sexual Assault Crimes Panel (June 2014) $18,19,20,21$

Dep't of Defense, Sex Crimes and the UCMJ: A Report for the Joint Service Committee on Military Justice (2005) $14,16,17,18$ 
Dep't of Defense, Judicial Proceedings Panel, Report on Retaliation Related to Sexual Assault Offenses (Feb. 2016)....................17, 20, 21

Dep't of Defense, Office of People Analytics, 2018 Workplace and Gender Relations Survey of Active Duty Members (May 2019).........20

Dep't of Veterans Affairs, Military Sexual Trauma (May 2015)

Kaitlin A. Chivers-Wilson, Sexual Assault and Posttraumatic Stress

Disorder: A Review of the Biological, Psychological and Sociological Factors and Treatments,

9 McGill J. Med. 111 (2006)

Memorandum from James N. Mattis, Sec'y of Defense, to All Members of Dep't of Defense: Sexual Assault Prevention and Awareness (Apr. 18, 2018) 16,17

Rebecca Campbell \& Sheela Raja, The Sexual Assault and Secondary Victimization of Female Veterans: Help-Seeking Experiences with Military and Civilian Social Systems, 29 Psychology of Women Q. 97 (2005) 


\section{INTEREST OF AMICI CURIAE}

Amici are Members of Congress committed to enforcing Congress' long-standing judgment that sexual violence has no place in the military and that no statute of limitations bars its prosecution. To this end, amici have all been involved in legislative efforts in this area and seek to defend Congress' decades-old policy of requiring punishment for rape in the military no matter how long ago the offense occurred.

Amici are:

- Rep. Brian Mast (R-FL)

- Rep. James R. Baird (R-IN)

- Rep. Gus Bilirakis (R-FL)

- Rep. Gilbert R. Cisneros Jr. (D-CA)

- Rep. Charlie Crist (D-FL)

- Rep. Ted Deutch (D-FL)

- Rep. Vicky Hartzler (R-MO)

- Rep. Denny Heck (D-WA)

- Rep. Kendra S. Horn (D-OK)

- Rep. Ann McLane Kuster (D-NH)

- Rep. Jackie Speier (D-CA)

- Rep. Haley Stevens (D-MI)

- Rep. Ted Yoho (D-FL)

\footnotetext{
* Pursuant to Supreme Court Rule 37.6, amici represent that this brief was not authored in whole or in part by any party or counsel for any party. No person or party other than amici or their counsel made a monetary contribution to the preparation or submission of this brief. Respondents have granted blanket consent to the filing of amicus curiae briefs and amici have received the written consent of the Government in accord with Supreme Court Rule 37.3.
} 


\section{STATEMENT}

1. In 2005, Air Force officer Michael Briggs went to the room of a member of his squadron and forced her to have sex with him-ignoring her exclamations of "no" and "stop" and her attempts to roll away from him. The rape was so violent that she bled for days; she was so bruised and swollen that she was unable to sit down. In 2000, Air Force course instructor Richard Collins pushed a student in his course against the wall, threw her to the floor, and struck her on the face before brutally raping her. And in 1998, Air Force airman Humphrey Daniels raped a civilian in the community near his air base-in the same bed where her child was sleeping.

2. Rape is always an evil and devastating crime-but the harm is compounded when it occurs in the highly regimented environment of the military, which stresses the imperative of respecting and deferring to authority. In a setting designed to inculcate swift and unquestioning obedience, rape is a uniquely harmful betrayal of trust.

For too long, these dynamics have frequently deterred survivors from reporting rape in the military. Because many survivors fear that their careers will be damaged if they report a rape committed by a superior, egregious criminal conduct all too often goes unpunished-depriving survivors of justice and poisoning the cohesion and effectiveness of the military.

Both Congress and the military have long been aware of these tragic realities. When the rapes in this case were committed, Articles 43(a) and 120(a) of the Uniform Code of Military Justice (UCMJ) treated rape as an "offense punishable by death" to which no 
statute of limitations applied. The Court of Appeals for the Armed Forces adopted that view twice over, reasoning in Willenbring v. Neurauter, 48 M.J. 152 (C.A.A.F. 1998), and United States v. Stebbins, 61 M.J. 366 (C.A.A.F. 2005), that the UCMJ recognized no temporal limitation on prosecutions for rape. In 2006, Congress amended the UCMJ to further clarify that no statute of limitations applies to rape in the military. See National Defense Authorization Act for Fiscal Year 2006 (2006 NDAA) § 553(a), Pub. L. No. 109-163, 119 Stat. 3136, 3264.

3. Following that amendment, the three survivors in these cases came forward-and justice was served. In 2014, 2016, and 2017, courts-martial found Briggs, Collins, and Daniels guilty of rape, dismissed them from the Air Force, and sentenced them to confinement.

But in 2018, the Court of Appeals for the Armed Forces broke from long-standing consensus and imported civilian death-penalty jurisprudence into the context of military discipline. Because this Court has held that it violates the Eighth Amendment to impose the death penalty for rape in the civilian context, the court of appeals reasoned that rape no longer constitutes an "offense punishable by death" under the UCMJ, and so-in contravention of the statute's clear text and Congress' important purposes - the court of appeals grafted a five-year statute of limitations onto the crime of rape in the military.

4. That decision reflects a profound misunderstanding of the governing legal framework that will have grave consequences if permitted to stand. 
First, the decision ignores the relevant text, structure, and legislative history to reach a conclusion wholly alien to the meaning of the UCMJ. Although this Court has the authority to decide which punishments may be constitutionally imposed for particular offenses, the power to determine which punishments are warranted belongs to Congress-particularly in the context of the military, which the Constitution explicitly tasks Congress with regulating. The court of appeals erred by rewriting statutory text and obliterating these congressional judgments.

Second, the decision overrides a congressional determination - that no statute of limitations bars the prosecution of rape in the military-which rests on critical policy judgments about the harms caused by rape in the military. In addition to the profound harms suffered by individual victims, rape has a devastating effect on unit cohesion and morale, and the military's hierarchical structure tends to deter survivors from coming forward. Recognizing these devastating harms, Congress adopted a policy of treating rape in the military as an "offense punishable by death"-and nothing permits, much less requires, that policy judgment to be set aside.

\section{SUMMARY OF ARGUMENT}

The Constitution entrusts Congress with authority over military discipline, including the authority to determine what (if any) statutes of limitations apply to crimes that occur within the military. By classifying rape as an "offense punishable by death" and stipulating that "offenses punishable by death" are not subject to statutes of limitations, Congress entrenched the policy that rape within the military is not 
subject to any statute of limitations at all. Whether the death penalty can be constitutionally imposed for the rape of an adult-an open question in the specialized military context-is wholly irrelevant to the key question here: Whether Congress determined that the death penalty is warranted for rape in the military. In answering "no," the court below flouted the text, structure, and history of the statute; departed from long-standing precedent (including its own); and overrode Congress' policy judgment on a matter of grave importance to both service members as individuals and the military as a whole.

Congress' policy judgment-that rape within the military is so heinous and so damaging to military effectiveness that no temporal restriction should be placed on its prosecution -is entitled to respect. Rape in the military has devastating effects on survivors individually and military readiness generally. And the military's hierarchical command structure can exacerbate the understandable reluctance of rape survivors to come forward and report the crimes committed against them. In light of those considerations, the provisions in the Uniform Code of Military Justice that address rape in the military have been understood for decades to reflect Congress' intent that those who commit the crime of rape should not be permitted to escape justice by hiding behind the passage of time. This Court should interpret the Uniform Code of Military Justice to reflect that intent and fulfill Congress' exceedingly important purposes in declining to subject the prosecution of rape in the military to temporal limitation. 


\section{ARGUMENT}

\section{The Decision Below Undermines CONGRESS' AUTHORITY OVER MILITARY Discipline BY REWRITING THE UNIFORM CODE OF Military Justice.}

The Constitution vests authority over the framework of military discipline exclusively in Congress. Article I expressly assigns to Congress the power "[t]o make Rules for the Government and Regulation of the land and naval Forces.” U.S. Const. art. I, § 8, cl. 14. Accordingly, it has long been recognized that "the Legislative Branch has plenary control over $* * *$ the framework of the military establishment, including regulations, procedures and remedies related to military discipline." Chappell v. Wallace, 462 U.S. 296, 301 (1983). ${ }^{1}$ And this Court has deferred to congressional regulation of the military in myriad contexts. See Solorio v. United States, 483 U.S. 435, 447-48 (1987) (collecting cases and detailing judicial deference to Congress' regulation of the military in the areas of free exercise, racial discrimination, sex discrimination, free expression, right to counsel, and due process).

1 See also Burns v. Wilson, 346 U.S. 137, 140 (1957) ("Military law $* * *$ exists separate and apart from the law which governs in our federal judicial establishment. $* * *$ The Framers expressly entrusted that task to Congress."); Dynes v. Hoover, 61 U.S. (20 How.) 65, 79 (1857) ("Congress has the power to provide for the trial and punishment of military and naval offences."); Loving v. United States, 517 U.S. 748, 777-78 (1996) (Thomas, J., concurring in the judgment) ("In light of Congress' express constitutional authority to regulate the Armed Forces, and the unique nature of the military's mission, we have afforded an unparalleled degree of deference to congressional action governing the military.") (internal citation omitted). 
Congress' power to regulate military discipline goes hand in hand with its power to establish statutes of limitations that govern the prosecution of improper conduct. Statutes of limitations "reflect[] a policy judgment by the legislature" regarding when (if at all) "the lapse of time" renders "criminal acts ill suited for prosecution." Smith v. United States, 568 U.S. 106, 112 (2013).

The decision below seriously undermines Congress' plenary authority over military discipline by erroneously imposing a five-year limitations period on prosecuting rapes in the military perpetrated before 2006. As text, structure, and history all make abundantly clear, that most certainly was not Congress' intent. Cf. United States v. Kubrick, 444 U.S. 111, 125 (1979) (statutes of limitations should be given "effect in accordance with what [the Court] can ascertain the legislative intent to have been").

Congress considers rape in the military to be among the most heinous offenses that can be committed, and its express constitutional authority to regulate military discipline is seriously eroded when courts fail to apply its enactments by their plain and unmistakable terms.

\section{A. Statutory Text And Structure Unmis- takably Reflect Congress' Determina- tion That No Statute Of Limitations Should Apply To Rape In The Military.}

At the time respondents raped their victims, the text of the UCMJ unambiguously reflected Congress' determination that rape in the military is not subject to a statute of limitations. Article 120 provided that 
rape "shall be punished by death or such other punishment as a court-martial may direct." 10 U.S.C. § 920(a) (1994 \& 2000). ${ }^{2}$ And Article 43 stated that "any offense punishable by death[] may be tried and punished at any time without limitation." 10 U.S.C. § 843(a) (1994 \& 2000) (emphasis added). ${ }^{3}$

Those two clauses plainly expressed Congress' policy determination that rape is so repugnant-and so destructive to military readiness-that perpetrators cannot be shielded by any statute of limitations. For over two decades, the Court of Appeals for the Armed Forces read those two interdependent clauses to mean exactly what they said. See Willenbring, 48 M.J. at 178-80 ("rape is an 'offense punishable by

2 Rape in the military has been punishable by death for "more than a century." Kennedy v. Louisiana, 554 U.S. 945, 946 (2008) (statement of Kennedy, J., joined by Stevens, Souter, Ginsburg, and Breyer, JJ., respecting the denial of rehearing) (citing Enrollment Act $\S 30$, ch. 75, 12 Stat. 731, 736 (1863)); see also Gov’t Br. 34. When Congress first enacted the UCMJ in 1950, it made rape in the military committed during peacetime punishable by death as well. See Act of May 5, 1950 (1950 UCMJ) art. 120(a), ch. 169, Pub. L. No. 81-506, 64 Stat. 107, 140 (1950) (“Any person subject to this code who commits an act of sexual intercourse $* * *$ by force and without [ ] consent, is guilty of rape and shall be punished by death or such other punishment as a court-martial may direct.").

3 Congress eliminated the statute of limitations for all offenses "punishable by death" in 1986. See National Defense Authorization Act for Fiscal Year 1987 (1987 NDAA) § 805(a), Pub. L. No. 99-661, 100 Stat. 3816, 3908 (1986) (“A person charged with absence without leave or missing movement in time of war, or with any offense punishable by death, may be tried and punished at any time without limitation.") (emphasis added); compare 1950 UCMJ art. 43(a), 64 Stat. at 121 ("A person charged with desertion or absence without leave in time of war, or with aiding the enemy, mutiny, or murder, may be tried and punished at any time without limitation."). 
death' for purposes of exempting it from the 5-year statute of limitations of Article 43"); Stebbins, 61 M.J. at 369 (reaffirming Willenbring).

Then, in 2018, the court of appeals reversed course and held - contrary to the statutes' plain text and Congress' clear intent-that the crime of rape in the military is subject to a five-year statute of limitations. United States v. Mangahas, 77 M.J. 220, 222-25 (C.A.A.F. 2018) (overruling Willenbring and Stebbins and holding that "rape is not exempt from the five-year statute of limitations"). The court reached that new conclusion by importing this Court's civilian deathpenalty jurisprudence into the military context. The court reasoned that-because executing a civilian rapist would violate the Eighth Amendment under this Court's precedents-rape in the military could not technically be "punishable by death," which meant that a limitations period must apply. Ibid. (citing Coker v. Georgia, 433 U.S. 584, 598 (1977)). ${ }^{4}$

The court of appeals' decision is profoundly flawed. For one thing, its approach to statutory interpretation makes little sense. The court of appeals held, in essence, that the meaning of the statutory phrase "punishable by death" turned not on the punishment Congress explicitly authorized in the UCMJ, but instead on whether the court of appeals thought this Court would deem that punishment constitutionally permissible. Id. at 223 (rape not "punishable by death" because although "the UCMJ authorized the

4 Amici agree with the Government that the court of appeals erred by importing civilian death-penalty jurisprudence into the military-discipline context. See Gov't Br. 22-23, 31-39; see also Briggs Pet. 16-20; Collins Pet. 14. 
death sentence[] for rape, $* * *$ such punishment cannot be constitutionally inflicted"). In so doing, the court endorsed an approach to interpretation that would make it virtually impossible for courts to ascertain the meaning of any statute with certainty, as it would require overlaying predicted constitutional outcomes on top of the text that Congress actually adopted.

For another thing, Congress' meaning was perfectly clear. The interlocking provisions of Articles 43 and 120 make plain that-for limitations purposesCongress intended the phrase "punishable by death" to be defined statutorily, not judicially. At the time respondents raped their victims, Article 43 provided that there was no limitation on prosecuting offenses that Congress deemed so detrimental to military readiness that they were "punishable by death." 10 U.S.C. $\S 843$ (a) (1994 \& 2000). By providing that rape could "be punished by death," Article 120 conveyed Congress' determination that rape was precisely that type of offense. 10 U.S.C. § 920(a) (1994 \& 2000). ${ }^{5}$

Neither the Mangahas decision, nor any of the respondents in this case, offers a coherent reason why Congress would have intended the application of the UCMJ's statute of limitations to turn on past and future judicial determinations about whether an offense's maximum punishment would be constitutionally permissible. More logically, application of the

5 Further highlighting the differences between the civilian and military contexts is the fact that Article 43 also provided that no statute of limitation applied to offenses that have no parallel in the civilian context, like being absent without leave and missing movement in a time of war. 10 U.S.C. § 843(a) (1994 \& 2000). 
UCMJ's statute of limitations turns on the punishment authorized by the UCMJ itself. After all, it is an elementary principle of statutory interpretation that the UCMJ, "like every Act of Congress, should not be read as a series of unrelated and isolated provisions," but rather as a whole. Gustafson v. Alloyd Co., 513 U.S. 561, 570 (1995).

Other courts have recognized this principle and acknowledged that whether an offense is "punishable by death" (or qualifies as a "capital" offense) for limitations purposes turns on the statutorily authorized punishments for the offense, not on whether a death sentence would be constitutionally permissible. See 18 U.S.C. $\S \S 3281,3282$. In United States v. Manning, for example, the Ninth Circuit reasoned:

If the statute's purpose derives from the nature of the offense with which the defendant is charged and not from the potential severity of the punishment, it remains in effect. After all, in a very literal sense, the offense defined [in the criminal statute] is still a "capital crime;" the statute still authorizes the imposition of the death penalty and Congress has not repealed it.

56 F.3d 1188, 1196 (9th Cir. 1995) (internal citations, quotation marks, and brackets omitted); see also United States v. Gallaher, 624 F.3d 934, 940-41 (9th Cir. 2010) ("'punishable by death' is a calibration of the seriousness of the crime as viewed by Congress, not of the punishment that could actually be imposed on the defendant in an individual case"); United States v. Payne, 591 F.3d 46, 58-59 (2d Cir. 2010) ("[I]n determining whether an offense is 'punishable by death' 
*** we look to the character of the offense and the penalties that are set out by statute. An offense 'punishable by death,' within the meaning of $\S 3281$, is one for which the statute authorizes death as a punishment, regardless of whether the death penalty is sought by the prosecution or ultimately found appropriate by the factfinder or the court."); United States v. Ealy, 363 F.3d 292, 296 (4th Cir. 2004) ("whether a crime is 'punishable by death' under $\S 3281$ or 'capital' under $\S 3282$ depends on whether the death penalty may be imposed for the crime under the enabling statute, not 'on whether the death penalty is in fact available for defendants in a particular case" "). ${ }^{6}$

In sum, the operative text and structure of the UCMJ plainly reflect Congress' intent that the prosecution of rape in the military is not to be subject to any temporal limitation.

\section{B. Legislative History Confirms What Stat- utory Text Makes Plain: Congress In- tended No Limitation On The Prosecu- tion Of Rape In The Military.}

In 1986, Congress amended Article 43 to eliminate the statute of limitations for "any offense punishable by death." 1987 NDAA $\S 805(a), 100$ Stat. at 3908. Before that amendment, the UCMJ already recognized that no limitation applied to the prosecution of murder. See 10 U.S.C. § 843(a) (1982) ("aiding the

6 Daniels's attempt to distinguish these cases on the ground that they involve murder rather than rape is misguided. See Daniels BIO 12-14. In each case, the defendant was not eligible for the death penalty. Nevertheless, each case held that the statute of limitations turned on the statutorily authorized punishment-not on whether death would have been a constitutionally permissible punishment. 
enemy, mutiny, or murder, may be tried and punished at any time without limitation"). Congress removed the limitations period from all offenses that were "punishable by death" to increase the likelihood that perpetrators who committed crimes most detrimental to military readiness would face prosecution and punishment.

Moreover, Congress identified such offenses statutorily-regardless of whether this Court might deem the authorized punishments constitutionally permissible at some future date. By explaining that "no statute of limitation would exist in prosecution of offenses for which the death penalty is a punishment prescribed by or pursuant to the UCMJ," the Senate Report to the 1986 amendment affirms that Congress intended Article 43 to be applied based on the UCMJ's text. S. Rep. No. 331, 99th Cong., 2d Sess. 249 (1986) (emphasis added). That is also consistent with the understanding of courts - then and now-that whether an offense was "punishable by death" turned on the statutorily authorized punishment, not the constitutionally permissible one. See Coon v. United States, 411 F.2d 422, 425 (8th Cir. 1969) (citing 18 U.S.C. $\S 3281$ ); see also United States v. Kennedy, 618 F.2d 557, 557-58 (9th Cir. 1980) (per curiam) ("punishable by death" analysis turns on "existing statutory language" not on this Court's constitutional interpretation) (citing 18 U.S.C. $§ 3148$ (1976)).

In 2006, Congress further amended Article 43 to make clear that both rape and rape of a child may be prosecuted without limitation. See 2006 NDAA $\S \S 552(\mathrm{e})-(\mathrm{f}), 553(\mathrm{a}), 119$ Stat. at 3263-64, codified at 10 U.S.C. § 843(a) (2006 \& Supp. I 2007). Those amendments followed a 2005 Department of Defense report that recommended adding "rape and rape of a child" 
to Article 43 to "clarif[y]" that Willenbring "is still good law and that there is an unlimited statute of limitations for all offenses that list death as a statutorily potential sentence- even if death is not a Constitutionally permitted punishment." Dep't of Defense, Sex Crimes and the UCMJ: A Report for the Joint Service Committee on Military Justice 285 (2005) ("Notwithstanding, the Coker prohibition against the death penalty for rape, the military statute of limitations for rape of an adult female should continue to be unlimited."). ${ }^{7}$

Congress was clear that the purpose of the amendment was not to alter the statute of limitations for rape in the military, but to "clarify that rape is also an offense with an unlimited statute of limitations." H.R. Conf. Rep. No. 360, 109th Cong., 1st Sess. 703 (2005) (emphasis added). In contrast, that same Conference Report stated that Congress was "extend[ing] the statute of limitations for certain child abuse offenses." Ibid. (emphasis added); see also H.R. Rep. No. 89, 109th Cong., 1st Sess. 332 (2005) (same).

Subsequent legislative history bears out this reading. In 2013, Congress again amended the UCMJ to provide-for the first time-that sexual assault in the military could be prosecuted without limitation. See National Defense Authorization Act for Fiscal Year $2014 \S 1703(a)$, Pub. L. No. 113-66, 127 Stat. 671, 958 (2013), codified at 10 U.S.C. § 843(a) (2012 \& Supp. II 2014) ("Elimination of five-year statute of limitations on trial by court-martial for additional offenses involving sex-related crimes") (capitalization altered). The Joint Explanatory Statement directly explained that

7 https://jpp.whs.mil/public/docs/03_Topic-Areas/02-Article_120 /20150116/58_Report_SexCrimes_UCMJ.pdf. 
Congress was "eliminat[ing] the 5-year statute of limitations $* * *$ for sexual assault." Joint Explanatory Statement, 159 Cong. Rec. H7984, at H7949 (2013) (emphasis added). Congress' use of "eliminate" further confirms that although Congress changed the limitations period applicable to sexual assault in 2013 , it merely clarified that rape in the military was subject to prosecution without limitation in 2006 .

The text, structure, and history of the UCMJ thus speak with one voice: No temporal limitation applies to the prosecution of respondents' rapes. The court of appeals' judgment to the contrary cannot stand.

\section{Congress Removed Any Limitations ON Prosecuting Rape In The Military To Achieve Critical Policy Goals.}

Congress' decision to impose severe penalties for rape in the military rests on its judgment that this crime-while always abhorrent-is uniquely pernicious in the military environment for at least two critical reasons. First, rape not only harms service members as individuals but also undermines the discipline, morale, and good order of the military as a whole. And second, the military context presents special difficulties that contribute to persistent underreporting that impedes the prosecution of rape.

\section{A. Congress Sought To Address The Unique Harms Associated With Rape In The Military.}

Since 1986, prosecution of rape in the military has not been subject to any temporal limitations-embodying Congress' long-standing judgment that rape in 
the military is uniquely harmful and must be met with the severest of penalties. ${ }^{8}$

In addition to its "devastating impact on victims," rape in the military "negatively affect[s] morale, good order and discipline and the unit cohesion and combat effectiveness of military personnel and units." Dep't of Defense, Sex Crimes and the UCMJ at 2-3; see also Gov't Br. 5-6, 34-35. Rape is "one of the most destructive factors in building a mission-focused military." Memorandum from James N. Mattis, Sec'y of Defense, to All Members of Dep't of Defense: Sexual Assault Prevention and Awareness (Apr. 18, 2018). ${ }^{9}$ Then-Secretary Mattis explained that "[u]nit cohesion is what holds us together under stress and keeps us combat effective when the chips are down." Ibid. Sexual violence poses an existential threat to the cohesion on which military readiness and effectiveness depend. ${ }^{10}$

8 That rape in the military has been punishable by death "since at least 1863" reflects the seriousness with which Congress has approached this heinous crime. Kennedy, 554 U.S. at 946 (statement of Kennedy, J., respecting the denial of rehearing); see also note 2 .

9 https://dod.defense.gov/portals/1/features/2018/0418_sapr /saap-osd004331-18-res.pdf.

10 About 20,500 "penetrative or contact sexual assault[s]" were reported across the Armed Forces in 2018, a 38 percent increase from 2016. Dep't of Defense, Annual Report on Sexual Assault in the Military: Fiscal Year 201810 (Apr. 2019), https://www.sapr .mil/sites/default/files/DoD_Annual_Report_on_Sexual_Assault _in_the_Military.pdf. The Department found that just over 6 percent of servicewomen and just under 1 percent of servicemen were victims of "sexual assault in the year prior to being surveyed." Ibid. For women, the rate of sexual assault or rape increased by over 50 percent- to the highest level in over a decade. Ibid. 
Unlike in the civilian context, where survivors can generally (though of course not always) try to avoid future contact with their assailants, there is no such latitude in the military. A survivor of rape in the military "deals with the rape and the impact on her community and also the ongoing influence of the offender on her life outside of that specific assault." Dep't of Defense, Judicial Proceedings Panel, Report on Retaliation Related to Sexual Assault Offenses 16 (Feb. 2016). ${ }^{11}$

After all, "[m]ilitary life requires that large numbers of young men and women live and work together in close quarters that are often highly isolated." Dep't of Defense, Sex Crimes and the UCMJ at 12. As a result, "[t]he deterrence of sexual offenses in such circumstances is critical to military efficiency." Ibid. As then-Secretary Mattis put it, "trust [is] the coin of the realm and our bedrock in building a cohesive team, one free of denigrating behavior." Mattis Memorandum. When that trust is broken, the team's effectiveness suffers as a result.

Above all, of course, is the profound harm rapists inflict on their victims. The most common effects are posttraumatic stress disorder, depression, and anxiety. Rape exacerbates the already prevalent problem of PTSD in the military: about half of all women who have been sexually assaulted experience PTSD. Kaitlin A. Chivers-Wilson, Sexual Assault and Posttraumatic Stress Disorder: A Review of the Biological, Psychological and Sociological Factors and Treatments, 9

11 http://jpp.whs.mil/Public/docs/08-Panel_Reports/04_JPP _Retaliation_Report_Final_20160211.pdf. 
McGill J. Med. 111, 112 (2006). ${ }^{12}$ Studies show that "depression occurred three times as often in women who were the victims of a sexual assault" in the military and that "sexual assault or harassment was more closely related to anxiety symptoms than combat stress." Dep't of Defense, Sex Crimes and the UCMJ at 50 .

A Veterans Affairs factsheet drives home the devastating and far-reaching effects of sexual assault, including strong emotions; feelings of numbness; trouble sleeping; difficulties with attention, concentration, and memory; substance abuse; relationship difficulties; and both physical and mental health problems. Dep't of Veterans Affairs, Military Sexual Trauma 12 (May 2015). ${ }^{13}$ Congress had ample reason to conclude that a crime inflicting this panoply of harms warrants the most severe punishment and should be prosecuted without regard to the passage of time.

\section{B. Underreporting Poses A Particular Challenge To Prosecuting Rape In The Military.}

Sexual assault "remain[s] chronically underreported when compared to reporting rates for other forms of violent crime." Dep't of Defense, Report of the Response Systems to Adult Sexual Assault Crimes

12 The process of post-rape care and investigation can itself trigger PTSD symptoms, referred to as "secondary victimization." Rebecca Campbell \& Sheela Raja, The Sexual Assault and Secondary Victimization of Female Veterans: Help-Seeking Experiences with Military and Civilian Social Systems, 29 Psychology of Women Q. 97, 97-106 (2005). A truncated limitations period can amplify the false message that the victim's trauma is not worth investigating.

13 https://www.mentalhealth.va.gov/docs/mst_general_factsheet .pdf. 
Panel 8 (June 2014). ${ }^{14}$ Survivors are often reluctant to come forward given "society's tendency to blame [them] for the crime" and because they "struggle[] with shame and self-blame; feelings of confusion, helplessness, and lack of control; and the fear of the consequences of reporting." Id. at 59. Tragically, last year nearly 70 percent of sexual assault victims in the military did not report the crime. Dep't of Defense, Annual Report Fiscal Year 2018 at 4, 10.

For survivors of rape in the military, the problem is even worse-they "face unique barriers to reporting that do not exist in the civilian world." Dep't of Defense, Response Systems at 60. Chief among these is the "hierarchical structure" that "focus[es] on obedience, order, and mission before self" that rests at the heart of military service. Ibid. Enlisted members "are taught blind obedience to every order" and are trained "to subordinate themselves in service of the larger goals and needs of the unit." Id. at 62 .

While this structure may be crucial to military success, it frequently exacerbates the chronic problem of underreporting. Id. at 60 . Where a perpetrator is a ranking superior, the survivor may be particularly wary of reporting as doing so may seem to go against the grain of "obedience" and "subordination"-in addition to concerns that "others will ignore or tend to disbelieve their allegations." Id. at 60-62. The problem is endemic. Among women who reported penetrative sexual assault, nearly 60 percent were assaulted by someone with a higher rank, and nearly 25 percent were assaulted by someone in their chain of command.

14 http://responsesystemspanel.whs.mil/Public/docs/Reports/00 _Final/RSP_Report_Final_20140627.pdf. 
Dep't of Defense, Office of People Analytics, 2018 Workplace and Gender Relations Survey of Active Duty Members 34 (May 2019). ${ }^{15}$

Moreover, given the close proximity in which service members typically live and work, "sexual assault allegation[s] involving members of the same military unit may divide loyalties among a close-knit group of people who should be working toward a common goal." Dep't of Defense, Response Systems at 60. Rather than risk the unity and cohesion of the unit, survivors of rape in the military often forego reporting in a tragic effort to place the unit's well-being above their own. See $i d$. at 62 ("As one sexual assault victim told the Panel: *** 'I felt that reporting [the sexual assault] would distract my unit and distract me from th[e] mission that I was given." ").

These considerations heighten the fear of reprisal that rape survivors often experience outside the military context: "The effects of retaliation on a victim can be particularly acute in the military environment because the accused and the victim often share the same community, the same peers, and the same mission." Dep't of Defense, Report on Retaliation at 16. These concerns are not unfounded. A 2014 survey by the RAND Corporation indicated that 62 percent of women on active military duty who reported unwanted sexual contact experienced some form of retaliation. $I d$. at 3,11 .

Similarly, the Department of Defense's 2012 Workplace and Gender Relations Survey revealed that 47 percent of women who did not report unwanted sexual

15 https://www.sapr.mil/sites/default/files/Annex_1_2018_WGRA _Overview_Report.pdf. 
contact were afraid of retaliation or thought they would be labeled as a troublemaker. Dep't of Defense, Response Systems at 60. Just as troubling, 43 percent of these women did not report unwanted sexual contact in light of the negative experience of other survivors who did come forward, and 28 percent were concerned that reporting would negatively affect their performance evaluation or chance for promotion. Id. at 60-61. This fear of retaliation works to "erode trust" in military organizations, "violates fundamental military values," and "undermines a commander's ability to maintain good order and discipline." Dep't of Defense, Report on Retaliation at 17. And it perpetuates an endless "cycle of sexual assault" and underreporting. $I d$. at 3.

That outcome is precisely what Congress has long been committed to addressing by insisting that perpetrators of sexual violence in the military must face justice, no matter how long ago they committed their crimes, and no matter how great the pressure on survivors to remain silent. Then and now, no statute of limitations prevents the prosecution of rape in the military-an offense so severe that Congress has determined it warrants the severest punishment. 


\section{CONCLUSION}

For the foregoing reasons, the judgment of the Court of Appeals for the Armed Forces should be reversed.

Respectfully submitted.

PAUL G. CASSELL

S.J. QUINNEY COLLEGE OF LAW AT THE UNIVERSITY OF UTAH* 383 South University Street Salt Lake City, Utah 84112

JOHN S. EHRETT GIBSON, DUNN \& CRUTCHER LLP 1050 Connecticut Avenue, NW Washington, D.C. 20036
ALLYSON N. Ho

Counsel of Record

BRADLEY G. HuBbARD

PHILIP AXT

JOSEPH E. BARAKAT ${ }^{\dagger}$ THOMAS M. MOLLOY, JR. GIBSON, DUNN \& CRUTCHER LLP 2001 Ross Avenue, Suite 2100 Dallas, Texas 75201 (214) 698-3100 aho@gibsondunn.com

\section{Counsel for Amici Curiae}

January 13, 2020

\footnotetext{
* Institutional information provided only for identification purposes; does not imply institutional endorsement.

$\dagger$ Admitted only in Washington, D.C.

* Admitted only in California.
} 